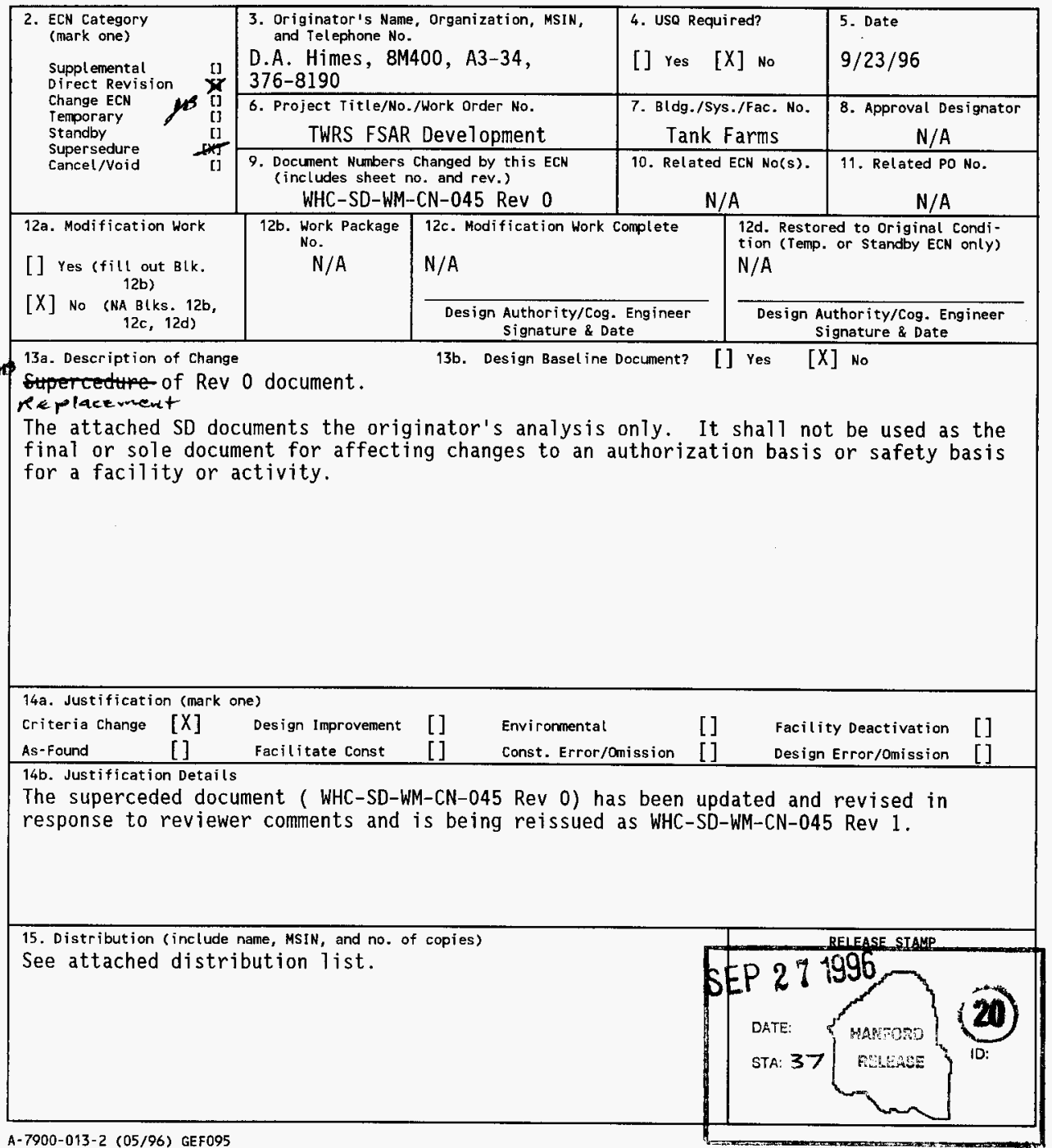


Page 2 of 2

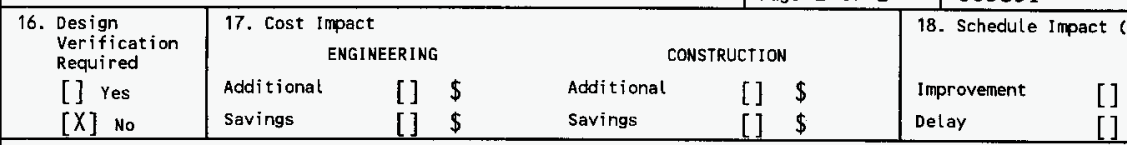

19. Change Impact Review: Indicate the related documents (other than the engineering documents identified on Side 1 ) that will be affected by the change deseribed in Block 13 . Enter the affected document number in 8 lock 20. SDD/DD

Functional Design Criteria

[] Seismic/Stress Analysis

Operating Specification

[].

Criticality Specification

Conceptual Design Report

[]

[]

[]

Equipment Spec

Const. Spec.

Procurement Spec.

Vendor Information

OM Manual

FSAR/SAR

Satety Equipment List

Radiation Work Permit

Environmental Impact Statement

Environmental Report

Environmental Permit

[]

[]

[]

[]

[]

[]

[]

[]

[]

[]

[]
Stress/Design Report

Interface Control Drawing

Calibration Procedure

Installation Procedure

Maintenance Procedure

Engineering Procedure

Operating Instruction

Operating Procedure

Operational Safety Requirement

IEFD Drawing

Coll Arrangement Drawing

Essential Material Specification

Fac. Proc. Samp. Schedule

Inspection Plan

Inventory Adjustment Request
[]

[]

[]

[]

[]

[]

[]

[]

[]

[]

[]

[]

[]

[]

[]

Tank Calibration Manual

Health Physics Procedure

Spares Multiple Unit Listing

Test Procedures/Specification

Component Index

ASME Coded ttem

Human Factor Consideration

Computer Software

Electric Circuit Schedule

ICRS Procedure

Process Control Manual/Plan

Process Flow Chart

Purchase Requisition

Tickler File

Tickler Fil

NONE indicate that the signing organization has been notified of other affected documents $l i s t e d$ below. Document Number/Revision Document Number/Revision

$N / A$

Document Number Revision

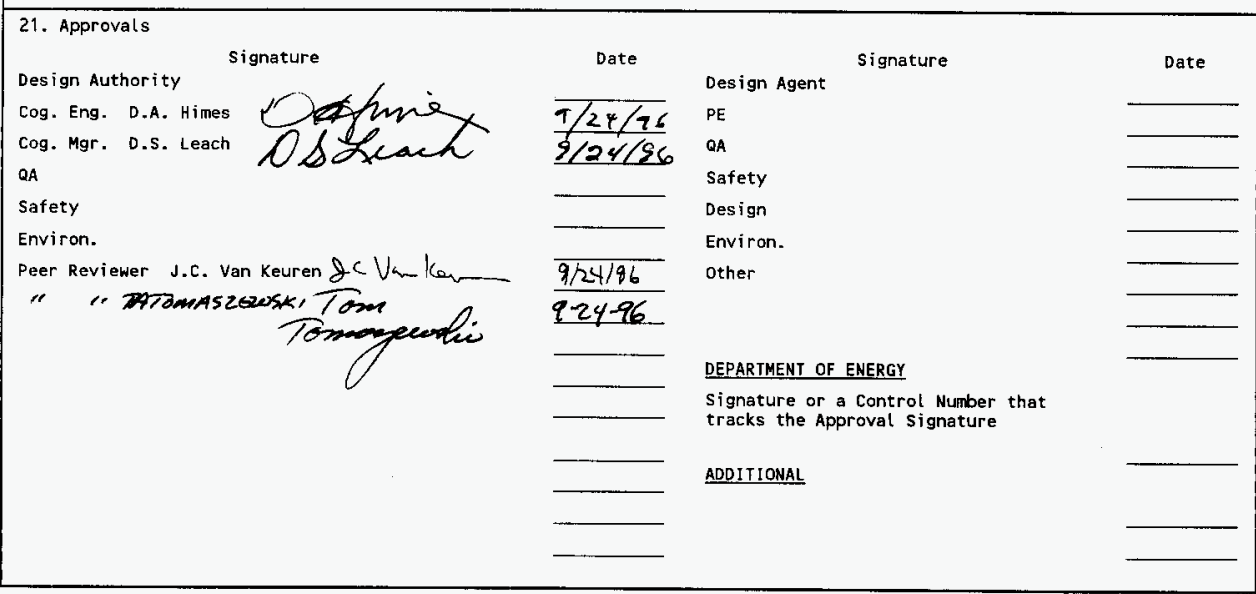




\section{Consequence Analysis of a Postulated NaOH Release from the 2727-W Sodium Storage Facility}

\section{D.A. Himes}

Westinghouse Hanford Company, Richland, WA 99352

U.S. Department of Energy Contract DE-AC06-87RL10930
EDT/ECN: 609891
Org Code: $8 \mathrm{M} 400$
UC: 512
B\&R Code: EW3120071
Charge Code: N1FC3
Total Pages: 7314

Key Words: Sodium Fire, Sodium Storage, 2727-W

Abstract: Toxicological and radiological consequences were calculated for a maximum sodium fire in the 2727-W Sodium Storage Facility. The sodium is solid and cannot leak out of the tanks. The maximum fire therefore corresponded to the maximum cross-sectional area of one tank. It was shown that release of the entire facility inventory of ${ }^{22} \mathrm{Na}$ is insufficient to produce an appreciable effect.

IRADEMARK DISCLAIMER. Reference herein to any specific comercial product, process, or service by trade name, trademark, manufacturer, or otherwise, does not necessarily constitute or imply its endorsement, recomendation, or favoring by the United States Government or any agency thereof or its contractors or subcontractors.

Printed in the United States of America. To obtain copies of this document, contact: WHC/BCS Document Control Services, P.O. Box 1970, Mailstop H6-08, Richland WA 99352, Phone (509) 372-2420; Fax (509) 376-4989.
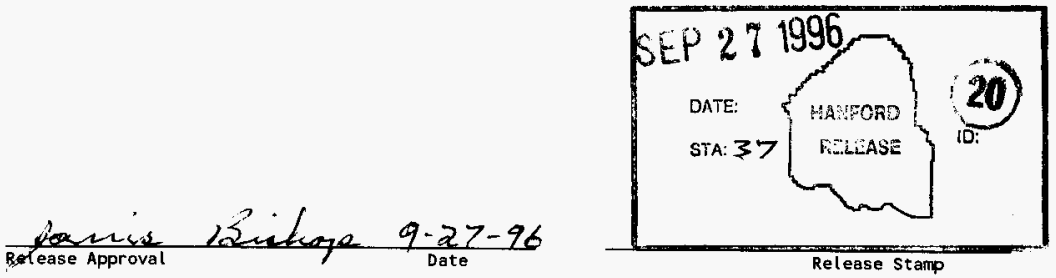

\section{Approved for Public Release}




\section{RECORD OF REVISION}

(2) Titie

Consequence Analysis of a Postulated $\mathrm{NaOH}$ Release from the 2727-W Sodium Storage

Facility

CHANGE CONTROL RECORD

\begin{tabular}{|c|c|c|c|c|}
\hline \multirow{2}{*}{ (3) } & \multirow{2}{*}{ Revision } & \multirow{2}{*}{ (4) Description of Change - Replace, Add, and Delete Pages } & \multicolumn{2}{|c|}{ Authorized for Release } \\
\hline & & & (5) Cog. Engr. & (6) Cog. Mgr. \\
\hline & 0 & (7) New document released via EDT \#142659 & $\begin{array}{l}\text { D.A. Himes } \\
7 / 30 / 96\end{array}$ & $\begin{array}{l}\text { D.S. Leach } \\
7 / 31 / 96\end{array}$ \\
\hline & $1 \mathrm{RS}$ & $\begin{array}{l}\text { Stpefeede revision } 0 \text { document via } \\
\text { ECN } \# 609891\end{array}$ & $\begin{array}{l}\text { D.A. Himes } \\
\text { 280ing } \\
3 / 24 / 96\end{array}$ & $\begin{array}{l}\text { D.S. Leach } \\
\text { OA Xea } \\
8 / 24 / 96\end{array}$ \\
\hline & & & & \\
\hline & & & & \\
\hline & & & & \\
\hline & & & & \\
\hline & & & & \\
\hline & & & & \\
\hline & & & & \\
\hline & & & & \\
\hline & & & & \\
\hline & & & & \\
\hline & & & & \\
\hline & & & & \\
\hline & & & & \\
\hline & & & & \\
\hline & & & & \\
\hline & & & & \\
\hline & & & & \\
\hline & & & & \\
\hline & & & & \\
\hline & & & & \\
\hline & & & & \\
\hline & & & & \\
\hline & & & & \\
\hline & & & & \\
\hline & & & & \\
\hline & & & & \\
\hline & & & & \\
\hline & & & & \\
\hline & & & & \\
\hline
\end{tabular}




\title{
CONSEQUENCE ANALYSIS OF A POSTULATED NaOH RELEASE FROM THE 2727-W SODIUM STORAGE FACILITY
}

\author{
D.A. Himes \\ $9 / 20 / 96$
}

The 2727-W Facility houses five stainless steel tanks of solidified sodium in a pre-engineered, self-framing steel building on a raised concrete foundation about $80 \mathrm{~m}$ north of the 16 th $\mathrm{St}$. rail crossing in the $200 \mathrm{~W}$ Area. The tanks are $23 \mathrm{ft} 3$ in. $(7.1 \mathrm{~m})$ long by $14 \mathrm{ft}(4.3 \mathrm{~m})$ outside diameter (including insulation) and are mounted horizontally in the $28 \mathrm{ft}(8.5 \mathrm{~m})$ by $84 \mathrm{ft}(26 \mathrm{~m})$ building. These are very substantial stainless steel tanks (having been used as shipping containers for the sodium) with an insulating layer of refractory brick approximately $1 \mathrm{ft}$ thick covered by aluminum sheathing (DOE 1995). The sodium is slightly contaminated with ${ }^{22} \mathrm{Na}$ with a half 1 ife of $2.58 \mathrm{y}$. The present total facility inventory of ${ }^{22} \mathrm{Na}$ is estimated to be $0.005 \mathrm{Ci}$ in the total sodium inventory of approximately $276,0001 \mathrm{~b}(125,000 \mathrm{~kg})$ (WHC 1996a). The Preliminary Hazard Analysis for the 2727-W Sodium Storage Facility identified several possible scenarios for release of $\mathrm{NaOH}$. It has been judged that the only credible scenario is a partial building collapse and tank damage due to high wind with accompanying rain leading to a sodium-water reaction and a sodium fire in the damaged tank.

The approach taken here is to postulate a sodium pool fire with an area corresponding to the maximum cross-sectional area of one tank. Since the sodium is solid and cannot leak out of the tank, this will maximize the sodium release rate and will bound all of the accidents 1isted in the Preliminary Hazard Analysis. Only the maximum rate of release of $\mathrm{NaOH}$ is of interest here since it will be shown that the entire facility inventory of ${ }^{22} \mathrm{Na}$ is insufficient to produce an appreciable effect.

\section{Postulated Scenario:}

The initiating event is assumed to be a high wind which causes major damage to the the building. The building is rated for a wind loading of $20 \mathrm{lb} / \mathrm{ft}^{2}$ (WHC 1996) which corresponds to a fastest mile wind speed of $70 \mathrm{mph}$ (ANSI 1982). This fastest mile wind speed has a frequency of exceedance on the 200 Areas of about 2E-3/y (LLNL 1985).

A falling building member is assumed to break off a large pipe connection into the tank in such a way that the opening is pointing upward. The building roof is assumed to fail in such a way that rain is channeled into the tank opening. The wind is then assumed to slow to a low speed and a heavy rain begins to fall. 
WHC-SD-WM-CN-045 Rev 1

The rain is channeled into the open tank causing a vigorous sodium-water reaction which generates large amounts of hydrogen and heat. The hydrogen inside the tank is then assumed to be ignited causing an explosion which further damages and opens up the upper half of the tank and results in a sodium fire over the entire upper surface of the sodium within the tank. Two of the tanks are full, one is half full and the remaining two are nearly empty except for residual heels (DOE 1995). The tank which is half full is the one assumed to be damaged in order to maximize the exposed sodium area within the tank. It is not expected that enough energy would be available outside the tank to cause significant damage to any of the other tanks.

The rain is then assumed to stop and the wind speed to remain low in order to minimize washout of releases and maximize downwind exposures to the sodium combustion product release which is assumed to be converted entirely to $\mathrm{NaOH}$ in the moist air.

Given the major damage to the building due to high wind, the remainder of the scenario leading to the limiting sodium fire is very conservatively estimated to have a probability of $1 \%$ (engineering judgement by analyst). This implies an overall frequency for this accident of approximately $2 E-5 / y$ which is well within the extremely unlikely category $\left(10^{-4}\right.$ to $\left.10^{-6} / y\right)$.

\section{Description of postulated release:}

The postulated maximum release rate corresponds to a sodium pool fire with a size equal to the internal tank dimensions, i.e., $12 \mathrm{ft}(3.7 \mathrm{~m})$ diameter by 20 $\mathrm{ft}(6.1 \mathrm{~m})$ effective length based on the $1 \mathrm{ft}$ insulation thickness and the volume of the tank (DOE 1995). The maximum area of the fire is then $240 \mathrm{ft}^{2}$ $\left(22.3 \mathrm{~m}^{2}\right)$. No credit was taken for any fire suppression effects by the remains of the top half of the tank or presence of any $\mathrm{N}_{2}$ cover gas. The standard open pool sodium burn rate of $81 \mathrm{~b} / \mathrm{ft}^{2} \mathrm{hr}\left(10.8 \mathrm{~g} / \mathrm{m}^{2} \mathrm{~s}\right)$ with an aerosol release fraction of $35 \%$ were assumed (Foust 1978). Data on open sodium fires (Johnson 1979) indicates that about $90 \%$ of the sodium combustion product is $\mathrm{Na}_{2} \mathrm{O}$ with about $9 \% \mathrm{Na}_{2} \mathrm{CO}_{3}$ and less than $1 \% \mathrm{NaOH}$. Because of the ability of $\mathrm{Na}_{2} \mathrm{O}$ to react with water to form $\mathrm{NaOH}$, however, a 11 of the sodium released from the fire is normally assumed to come off as $\mathrm{NaOH}$ with $1 \mathrm{~g}$ of sodium producing $1.74 \mathrm{~g}$ of $\mathrm{NaOH}$. The resulting maximum $\mathrm{NaOH}$ release rate is $(22.3$ $\left.\mathrm{m}^{2}\right)\left(10.8 \mathrm{~g} / \mathrm{m}^{2} \mathrm{~s}\right)(0.35)(1.74)=147 \mathrm{~g} / \mathrm{s}$.

\section{TRANSPORT ASSUMPTIONS:}

Although a fire normally implies some degree of thermal lofting which would reduce ground level air concentrations (especially near the fire), the intensity of the fire, and therefore the degree of lofting, cannot be predicted. For this reason, fires are normally assumed to be ground level sources for purposes of estimating direct receptor exposures. For a ground 
level release the onsite receptor is normally assumed to be at a distance of $100 \mathrm{~m}$ in the worst direction (WHC 1988). The site boundary receptor for purposes of this analysis is located at the site boundary or the near bank of the Columbia River, whichever is closer, in the worst direction. No receptor evacuation was assumed.

Acute 99.5 percentile ground level release dispersion factors $(X / Q)$ have been generated using the GXQ code (Hey 1994) at each of the 16 sectors at $100 \mathrm{~m}$ and at the site boundary or the near bank of the Columbia River. Since toxicological exposures, and therefore maximum air concentrations, are normally the primary concern for a sodium fire, no plume meander was assumed. The resulting $X / Q$ S are reported in WHC-SD-WM-SARR-016 (Savino 1996) as $3.41 E-2$ $\mathrm{s} / \mathrm{m}^{3}$ onsite $(100 \mathrm{~m} \mathrm{E})$ and $2.83 \mathrm{E}-5 \mathrm{~s} / \mathrm{m}^{3}$ at the site boundary $(8.76 \mathrm{~km} \mathrm{~N})$.

\section{Radiological hazard:}

The sodium stored in the 2727-W Facility is slightly contaminated with ${ }^{22} \mathrm{Na}$ with a half-life of $2.58 \mathrm{y}$. The total facility inventory at the present time is estimated in the Preliminary Hazard Analysis to be about $0.005 \mathrm{Ci}$ (WHC 1996a). The dose due to a release $Q$ of ${ }^{22} \mathrm{Na}$ can be calculated using the standard formula Dose $=Q \times(X / Q) \times(B R) \times(D C F)$ where $B R$ is the light activity breathing rate $\left(3.3 \mathrm{E}-4 \mathrm{~m}^{3} / \mathrm{s}\right)$ and $D C F$ is the dose conversion factor. The dose conversion factor for ${ }^{22} \mathrm{Na}$ is $2.07 \mathrm{E}-9 \mathrm{SV} / \mathrm{Bq}(7.66 \mathrm{E}+3 \mathrm{rem} / \mathrm{Ci}$ ) (EPA 1988). The release of the entire facility inventory of ${ }^{22} \mathrm{Na}$ would therefore produce an inhalation dose of only $4.31 \mathrm{E}-4 \mathrm{rem}$ in the onsite receptor at $100 \mathrm{~m}$ $\mathrm{E}$ and $3.58 \mathrm{E}-7$ rem in the site boundary receptor at $8.76 \mathrm{~km} \mathrm{~N}$ on the near bank of the Columbia River. Both doses are negligible even for a non-mechanistic release of the entire building inventory. The corresponding risk evaluation guidelines for the extremely unlikely frequency range are $10 \mathrm{rem}(100 \mathrm{mSv})$ and 4 rem (40 mSv) (Bacon 1996) for the onsite and site boundary receptors, respectively.

\section{Toxicological exposures:}

By the definition of the $X / Q$, the maximum air concentration of $\mathrm{NaOH}$ at a receptor location is just the product of the maximum release rate and the receptor $X / Q$. A maximum release rate of $147 \mathrm{~g} / \mathrm{s}$ with no fallout would therefore produce a concentration of $5.01 \mathrm{E}+3 \mathrm{mg} / \mathrm{m}^{3}$ at the onsite receptor 100 $\mathrm{m}$ from the release point. The highest particulate concentration which can ordinarily be supported in the air at a point away from the source, however, is about $100 \mathrm{mg} / \mathrm{m}^{3}$ (ANSI 1981). This corresponds to a very heavy dust condition. Data from open sodium fires (Johnson 1979) indicates that, due to rapid agglomeration and fallout of the combustion particles in the first 50 to $100 \mathrm{~m}$, the air concentration at $100 \mathrm{~m}$ downwind is actually much lower (i.e., less than about $20 \mathrm{mg} / \mathrm{m}^{3}$ ) (see detailed discussion in attachment 1 ). Even so, since this effect cannot be quantified, $100 \mathrm{mg} / \mathrm{m}^{3}$ is normally conservatively 
assumed at a distance at least $100 \mathrm{~m}$ downwind of a heavy particulate source (WHC 1996b). The corresponding concentration at the site boundary can be calculated by using the ratio of the $X / Q s$ at the onsite and site boundary receptors. The maximum concentration at the site boundary is then $\left(100 \mathrm{mg} / \mathrm{m}^{3}\right)$ $x\left(2.83 \mathrm{E}-5 \mathrm{~s} / \mathrm{m}^{3}\right) /\left(3.41 \mathrm{E}-2 \mathrm{~s} / \mathrm{m}^{3}\right)=0.083 \mathrm{mg} / \mathrm{m}^{3}$.

\section{Conclusion:}

As previously demonstrated, the radiological effects of the ${ }^{22} \mathrm{Na}$ contamination in the sodium are negligible even if the entire facility inventory is released. (Any actual release would be much less.) The only effect of concern due to the maximum fire described here would be the toxicological exposure to the onsite receptor at $100 \mathrm{~m}$ downwind. For this receptor, the maximum air concentration was very conservatively estimated at $100 \mathrm{mg} / \mathrm{m}^{3}$ based on maximum air loading. For an accident frequency in the extremely unlikely range $\left(10^{-4}\right.$ to $\left.10^{-6} / \mathrm{y}\right)$ the onsite toxic limit is the ERPG-3. $\mathrm{NaOH}$ is classed as a corrosive/irritant with an ERPG-3 of $100 \mathrm{mg} / \mathrm{m}^{3}$ (Van Keuren 1995). The worst-case site boundary receptor would be exposed to an estimated maximum $\mathrm{NaOH}$ concentration of $0.083 \mathrm{mg} / \mathrm{m}^{3}$. The corresponding limit for this receptor is the ERPG-2 which for $\mathrm{NaOH}$ is $40 \mathrm{mg} / \mathrm{m}^{3}$ (Van Keuren 1995). The resulting sums of fractions (SOF) of the limits are therefore 1.0 and 0.0021 for the onsite and site boundary receptors, respectively.

\section{References:}

ANSI 1980, American National Standard - Guidance for Defining Safety-Related Features of Nuclear Fuel Cycle Facilities, ANSI N46.1-1980.

ANSI 1982, American National Standard - Minimum Design Loads for Buildings and other Structures, ANSI A58.1-1982.

Bacon 1996, Letter R.F. Bacon to J.E. Kinzer, USDOE Richland Operations office, "Tank Waste Remediation System Accident Analysis Risk Evaluation Guidelines," Westinghouse Hanford Company, 9651709, Apri1 22, 1996.

DOE 1995, Letter, Thomas K. Teynor to President of WHC, "Request for Relief of Department of Transportation (DOT) Regulations for Shipment of the HALLAM Sodium Tanks," Waste Programs Division, DOE Richland Operations Office, 95-SWT-448, Ju7y 26, 1995.

EPA 1988, Limiting Values of Radionuclide Intake and Air Concentration and Dose Conversion Factors for Inhalation, Submersion, and Ingestion, Federal Guidance Report No.11, EPA-520/1-88-020, September 1988.

Foust 1978, 0.J. Foust, ed., Sodium - NaK Engineering Handbook, Vol. III, 1978. 
Hey 1994, B.E. Hey, GXQ Program User's Guide, WHC-SD-GN-SWD-30002, Rev. 1, Westinghouse Hanford Company, Richland, Washington, Dec. 19, 1994.

Johnson 1979, R.P. Johnson, C. Guderjahn, H.A. Morewitz, C.T. Nelson, and J. Otter, "Atmospheric Fallout of Sodium Combustion Aerosols," Proceedings of the International Meeting on Fast Reactor Safety Technology, Rockwe11 International, pp. 814-822, August 1979.

LLNL 1985, National Phenomena Hazards Modelling Project: Extreme Wind/Tornado Models for Department of Energy Sites, Lawrence Livermore National Laboratory, UCRL-53526 Rev 1, 1985.

Savino 1996, A.V. Savino, Tank Waste Compositions and Atmospheric Dispersion Coefficients for use in Accelerated Safety Analysis Consequence Assessments, WHC-SD-WM-SARR-016 Rev 2, September 1996.

Van Keuren 1995, J.C. Van Keuren, J.S. Davis, and M.L. Dentler, Toxic Chemical Considerations for Tank Farm Releases, WHC-SD-WM-SARR-011 Rev 1, November 1995.

WHC 1988, Safety Analysis Manual, WHC-CM-4-46, Westinghouse Hanford Company, Richland Washington, September 30, 1988.

WHC 1996a, Hazard Evaluations for the TWRS FSAR, WHC-SD-WM-TI-759 Rev 0, September 1996.

WHC 1996b, Safety Assessment for Tank 241-C-106 Waste Retrieval Project W-320, WHC-SD-WM-SAD-024 Rev 0, May 1996. 
WHC-SD-WM-CN-045 Rev 1

Attachment 1

Estimation of $\mathrm{NaOH}$ Air Concentration at $100 \mathrm{~m}$ 
WHC-SD-WM-CN-045 Rev 1

\section{Estimation of $\mathrm{NaOH}$ Air Concentration at $100 \mathrm{~m}$ Based on Actual Test Data}

Five sodium combustion product release tests were conducted in the open atmosphere at the Idaho National Engineering Laboratory (INEL) (Johnson 1979). The purpose of the tests was to determine fallout distributions and characteristics (chemical and physical) of the combustion products. Four of the tests involved forcing hot sodium through jet and spray nozzles where it burned on contact with the air. The fifth test (test no. 4) involved a pool fire, but the fallout data were not tabulated. Tests no. 1 and 2 were chosen for comparison because the release was from moderate heights $(5$ and $6 \mathrm{~m}$, respectively), and because these two tests covered nearly the full range of the spread in downwind ground contamination data (see Figure 4 in the Reference). The ground contamination results from the pool fire (test no. 4) are included in the same figure and closely match the results from test no. 1. The releases in tests no. 3 and 5 were elevated $(30 \mathrm{~m})$ and were in the form of jets which tended to produce larger Na particle sizes. Tests 3 and 5 were therefore judged to be less representative of a ground level pool fire.

It was noted during these tests that there was a rapid initial fallout of the sodium combustion product particles leading to heavy deposition for about the first $50 \mathrm{~m}$ downwind of the fire. Beyond the first 50 to $100 \mathrm{~m}$ the fallout assumed the typical exponential decrease with distance (i.e., linear on a $\log -$ log plot) as expected. In addition, the particle size distribution was measured as a function of downwind distance for test no. 4 (the pool fire). The results show the expected decrease in particle sizes as one moves away from the source. At $100 \mathrm{~m}$ the median particle diameter was $35 \mu \mathrm{m}$ with a geometric deviation $\left(\sigma_{g}\right)$ of 1.67 while at $200 \mathrm{~m}$ the median diameter dropped to $20 \mu m$ with a $\sigma_{g}$ of 1.98 .

The conditions of tests no. 1 and 2 are shown in table 1 . Note that these were both spray releases with the wind speeds measured at the release heights. It was observed that very heavy fallout occurred within the first 50 to $100 \mathrm{~m}$ downwind even for the higher wind speeds (and therefore less fallout time).

Table 1: Conditions for sodium fire tests No. 1 and 2

\begin{tabular}{cccccc} 
Test No. Released $(\mathrm{kg})$ & $\begin{array}{c}\text { Release } \\
\text { Height }(\mathrm{m})\end{array}$ & $\begin{array}{c}\text { Release } \\
\text { Time }(\mathrm{s})\end{array}$ & $\begin{array}{c}\text { Wind } \\
\text { Speed (m/s) }\end{array}$ & $\begin{array}{c}\text { Stability } \\
\text { Category }\end{array}$ \\
\hline & 22.1 & 5 & 235 & 4.0 & D \\
2 & 25.1 & 6 & 315 & 4.2 & A
\end{tabular}


WHC-SD-WM-CN-045 Rev 1

The $35 \mu \mathrm{m}$ median particle size at $100 \mathrm{~m}$ implies a gravitational settling velocity given by Stokes equation in the form

$$
v_{g}=\frac{2 r^{2} g \rho}{9 \mu}
$$

where $r$ is the particle radius $(1.75 \mathrm{E}-5 \mathrm{~m}), \mathrm{g}$ is the gravitational acceleration $\left(9.8 \mathrm{~m} / \mathrm{s}^{2}\right), \rho$ is the density of the particle $\left(2.27 \mathrm{E}+6 \mathrm{~g} / \mathrm{m}^{3}\right.$ for $\left.\mathrm{Na}_{2} \mathrm{O}\right)$, and $\mu$ is the viscosity of air $(0.018 \mathrm{~g} / \mathrm{m} \cdot \mathrm{s})$. The resulting value for the settling velocity of the median particle is $8.4 \mathrm{~cm} / \mathrm{s}$. Knowing the release time from Table 1 above, the average air concentration at a point $100 \mathrm{~m}$ downwind of the source can then be deduced from the fact that the final ground deposition $\left(\mathrm{g} / \mathrm{m}^{2}\right)$ is equal to the average air concentration times the settling velocity times the plume passage time (approximately equal to the release time).

It is evident here that we are dealing with a particle size distribution rather than a single particle size. The $35 \mu \mathrm{m}$ median particle size means that half the particles were smaller and half were larger than this size. This, in turn, implies that half the particles had fall velocities less than $8.4 \mathrm{~cm} / \mathrm{s}$ and half the particles fell faster than $8.4 \mathrm{~cm} / \mathrm{s}$. The primary concern here, however, is not with particle fallout rates, but with mass fallout rates. In a particle size distribution, the larger particles obviously have larger masses per particle than the smaller particles. The mass weighted average particle diameter would therefore be larger than the median particle size of $35 \mu \mathrm{m}$, and hence the mass weighted average fall velocity would be higher than $8.4 \mathrm{~cm} / \mathrm{s}$. Using the lower value of $8.4 \mathrm{~cm} / \mathrm{s}$ therefore over estimates the mass air loading and the results are conservative in this regard.

Average measured sodium ground contamination levels at $100 \mathrm{~m}$ were reported as $1.9 \mathrm{E}-2 \mathrm{~g} / \mathrm{m}^{2}$ and $1.6 \mathrm{E}-2 \mathrm{~g} / \mathrm{m}^{2}$ for test 1 and test 2 , respectively. The corresponding derived air concentrations are $0.96 \mathrm{mg} / \mathrm{m}^{3} \mathrm{Na}\left(1.7 \mathrm{mg} / \mathrm{m}^{3} \mathrm{NaOH}\right)$ and $0.60 \mathrm{mg} / \mathrm{m}^{3} \mathrm{Na}\left(1.1 \mathrm{mg} / \mathrm{m}^{3} \mathrm{NaOH}\right)$. Note that the effective $\mathrm{NaOH}$ release rates for these two tests were $164 \mathrm{~g} / \mathrm{s}$ and $139 \mathrm{~g} / \mathrm{s}$ which are nearly identical to the release rate of $147 \mathrm{~g} / \mathrm{s}$ assumed for the fire described in the main document. (The usual $35 \%$ aerosol release fraction was not applied here since these were elevated spray fires.)

The relatively high wind speeds and neutral to unstable atmospheric conditions present during these tests would tend to increase the dispersion (i.e., decrease the $X / Q$ ) and are far from worst-case. The increased turbulence and decreased transport time accompanying such conditions, however, would also produce a competing decrease in the short range fallout rate. Note that the difference in conditions between tests 1 and 2 would produce a decrease in $X / Q$ by about a factor of 8 due primarily to the differences in the dispersion coefficients $\sigma_{y}$ and $\sigma_{z}$ between Pasquill D and Pasquill A stability. Yet the 
final ground contamination level per unit release for test 2 is only $30 \%$ less than that for case 1 .

The two inferred average air concentrations shown above are expected to be somewhat less than the maximum air concentrations because (1) samples were taken in a $90^{\circ}$ arc (to include plume meander) and averaged, whereas the sodium fire plume was observed to cover only about a $30^{\circ}$ arc. Even allowing a factor of 10 for this effect, however, would still indicate air concentrations far less than the $100 \mathrm{mg} / \mathrm{m}^{3}$ maximum air loading usually assumed for conservatism. 
WHC-SD-WM-CN-045 Rev 1

\section{CHECKLIST FOR PEER REVIEW}

Document Reviewed: CONSEQUENCE ANALYSIS OF A POSTULATED NaOH RELEASE FROM THE 2727-W SODIUM STORAGE FACILITY, WHC-SD-WM-CN-045 Rev 1 ,

Scope of Review: D.A. Himes, $9 / 20 / 96$

Yes No NA

[X] [] [ ] * Previous reviews complete and cover analysis, up to scope of this review, with no gaps.

$凶]$ [ ] [ ] Problem completely defined.

X] [ ] [ ] Accident scenarios developed in a clear and logical manner. Necessary assumptions explicitly stated and supported.

Computer codes and data files documented.

Data used in calculations explicitly stated in document.

Data checked for consistency with original source information as applicable.

[ ] [ ] [ $\rtimes$ Mathematical derivations checked including dimensional consistency of results.

$凶$ [ ] [ ] Models appropriate and used within range of validity or use outside range of established validity justified.

[X] [ ] [ ] Hand calculations checked for errors. Spreadsheet results should be treated exactly the same as hand calculations.

$\left[\begin{array}{llll}{[} & {[} & {[} & \mathbb{X}\end{array}\right]$

$\infty[$ ] [ ]

Software input correct and consistent with document reviewed.

Software output consistent with input and with results reported in document reviewed.

Limits/criteria/guidelines applied to analysis results are appropriate and referenced. Limits/criteria/guidelines checked against references.

Safety margins consistent with good engineering practices.

Conclusions consistent with analytical results and applicable limits.

[X] [ ] [ ] Results and conclusions address all points required in the problem statement.

[ ] [ ] D] Format consistent with appropriate NRC Regulatory Guide or other standards

[ ] $\triangle]^{*}$ Review calculations, comments, and/or notes are attached.

$\bowtie][$ ] [ ] Document approved.

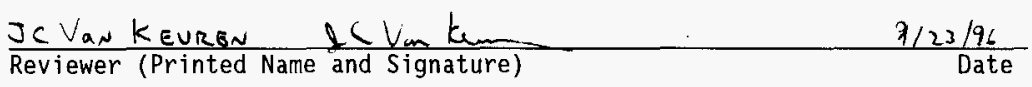

* Any calculations, comments, or notes generated as part of this review should be signed, dated and attached to this checklist. Such material should be labeled and recorded in such a manner as to be intelligible to a technically qualified third party. 
WHC-SD-WM-CN-045 Rev 1

\section{HEDOP REVIEW CHECKLIST \\ for \\ Radiological and Nonradiological Release Calculations}

Document reviewed (include title or description of calculation, document number, author, and date, as applicable):

CONSEQUENCE ANALYSIS OF A POSTULATED NaOH RELEASE FROM THE 2727-W SODIUM STORAGE FACILITY, WHC-SD-WM-CN-045 Rev 1, D.A. Himes, 6/21/96

Submitted by: D.A. Himes Date Submitted:

Scope of Review: entire document

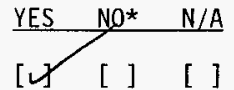

1. A detailed technical review and approval of the environmental transport and dose calculation portion of the analysis has

[4 [ ] [ ] 2. Detailed technical review(s) and approval(s) of scenario and release determinations have been performed and documented.

[ ] [ ] [ [ 3. HEDOP-approved code(s) were used.

[ ] [ ] [ ] 4. Receptor locations were selected according to HEDOP recommendations.

[4 [ ] [ ] 5. A1l applicable environmental pathways and code options were

[4 [ ] [ ] 6. Hanford site data were used.

[4 [ ] [ ] 7. Model adjustments external to the computer program were justified and performed correctly.

[ ] [ ] [ 8. The analysis is consistent with HEDOP recommendations.

[ ] [ 9 . Supporting notes, calculations, comments, comment resolutions, or other information is attached. (Use the "Page 1 of $X$ " page numbering format and sign and date each added page.)

[于 [ ] 10. Approval is granted on behalf of the Hanford Environmental Dose Overview Panel.

* All "NO" responses must be explained and use of nonstandard methods justified.

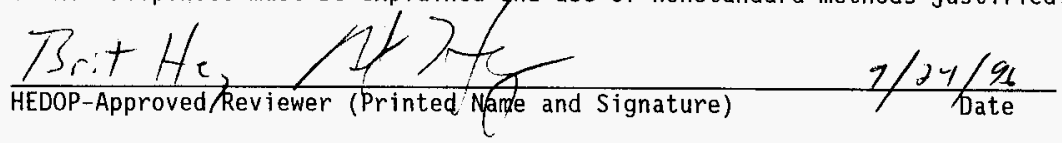

COMMENTS (add additional signed and dated pages if necessary): 


\section{CHECKLIST FOR PEER REVIEW}

Document Reviewed:

Consequence Analysis of a Postulated NaOH Release from the 2727-W Sodium Storage Facility, WHC-SD-MN-CN-045, Revision 1.

Scope of Review: This review was limited to confirming that the comments to Rev 0 provided by this reviewer were dispositioned and/or incorporated into Rev 1 to my satisfaction, including the addition of the SOF at the end of the conclusion.

$\frac{\text { Yes No NA }}{[\mathrm{X}][][]}$ *

$\left.\begin{array}{lll}{[X]} & {[} & {[} \\ {[X]} & {[} & {[} \\ {[X]} & {[} & {[} \\ {[x]} & {[} & {[x]} \\ {[X]} & {[} & {[}\end{array}\right]$

[X] [ ] [ ]

[X] [ ] [ ]

[X] [ ] [ ]

$\left[\begin{array}{llll}{[} & {[}\end{array}\right]\left[\begin{array}{l}X \\ {[]}\end{array}\right]\left[\begin{array}{l}X \\ X\end{array}\right]$

[X] [ ] [ ]

$\begin{array}{lll}{[X]} & {[} & {[} \\ {[X]} & {[} & {[X]} \\ {[X]} & {[} & {[}\end{array}$

[X] [ ] [ ]

[ ] [ ] $[\mathrm{X}]$

[ ] $[X]$ *

Previous reviews complete and cover analysis, up to scope of this review, with no gaps.

Problem completely defined.

Accident scenarios developed in a clear and logical manner. Necessary assumptions explicitly stated and supported.

Computer codes and data files documented.

Data used in calculations explicitly stated in document.

Data checked for consistency with original source information as applicable.

Mathematical derivations checked including dimensional consistency of results.

Models appropriate and used within range of validity or use outside range of established validity justified.

Hand calculations checked for errors. Spreadsheet results should be treated exactly the same as hand calculations.

Software input correct and consistent with document reviewed.

Software output consistent with input and with results reported in document reviewed.

Limits/criteria/guidelines applied to analysis results are appropriate and referenced.

Limits/criteria/guidelines checked against references.

Safety margins consistent with good engineering practices.

Conclusions consistent with analytical results and applicable limits.

Results and conclusions address all points required in the problem statement.

Format consistent with appropriate NRC Regulatory Guide or other standards

[X] [ ] [ ] Document approved.

Tom Tomaszewski Tand 9/24/96

Reviewer (Printed Name and Signaturg)

Date

* Any calculations, comments, or notes Generated as part of this review should be signed, dated and attached to this checklist. Such material should be labeled and recorded in such a manner as to be intelligible to a technically qualified third party. NONE ATTACHED.

[ ] [ ] [X] Analysis entered into-analysis databas

Iom Tomaszewski

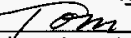

oncarpecole

(Printed Name and Signature)

12

9/24/96

Date 


\section{DISTRIBUTION SHEET}

\begin{tabular}{|c|c|c|c|c|c|}
\hline \multirow{2}{*}{$\begin{array}{l}\text { To } \\
\text { Consequence Analysis } 8 M 400\end{array}$} & \multirow{2}{*}{\multicolumn{3}{|c|}{ From }} & \multicolumn{2}{|l|}{ Page 1 of 1} \\
\hline & & & 1400 & \multicolumn{2}{|c|}{ Date $9 / 23 / 96$} \\
\hline \multirow{2}{*}{\multicolumn{4}{|c|}{$\begin{array}{l}\text { Project Title/Work Order } \\
\text { Consequence Analysis of a Postulated } \mathrm{NaOH} \text { Release from the } \\
2727-W \text { Sodium Storage Facility }\end{array}$}} & \multirow{2}{*}{\multicolumn{2}{|c|}{\begin{tabular}{|ll} 
EDT No. & $\mathrm{N} / \mathrm{A}$ \\
ECN No. & 609891
\end{tabular}}} \\
\hline & & & & & \\
\hline \multicolumn{2}{|l|}{ Name } & $\begin{array}{l}\text { Text } \\
\text { With All } \\
\text { Attach. }\end{array}$ & Text Only & $\begin{array}{l}\text { Attach./ } \\
\text { Appendix } \\
\text { Only }\end{array}$ & $\begin{array}{l}\text { EDT/ECN } \\
\text { Only }\end{array}$ \\
\hline $\begin{array}{l}\text { C. Carro } \\
\text { G.N. Hanson } \\
\text { D.F. Hicks } \\
\text { D.A. Himes (2) } \\
\text { M.V. Shultz } \\
\text { J.L. Stewart } \\
\text { A.R. Tedeschi } \\
\text { R.P. Tucker } \\
\text { J.C. Van Keuren } \\
\text { J. Young } \\
\text { Central Files (original }+3 \text { ) } \\
\text { Docket Files (2) } \\
\text { TWRS S \& L Project Files (4) }\end{array}$ & $\begin{array}{l}\text { A2-34 } \\
\text { S5-05 } \\
\text { A2-34 } \\
\text { A3-34 } \\
\text { A3-34 } \\
\text { A2-26 } \\
\text { R1-56 } \\
\text { T4-00 } \\
\text { A3-34 } \\
\text { A2-34 } \\
\text { A3-88 } \\
\text { B1-17 } \\
\text { A2-26 }\end{array}$ & $\begin{array}{l}x \\
X \\
X \\
X \\
X \\
x \\
x \\
X \\
X \\
x \\
x \\
x \\
x \\
x \\
x\end{array}$ & & & \\
\hline
\end{tabular}

